\title{
Determination of Thermal Properties and Morphology of Eucalyptus Wood Residue Filled High Density Polyethylene Composites
}

\section{Fatih Mengeloglu * and Ayse Kabakci}

Department of Forest Industry Engineering, Kahramanmaras Sutcuimam University, Kahramanmaras, Turkey; E-mail: fmengelo@ksu.edu.tr, ayse_kabakci@hotmail.com

* Author to whom correspondence should be addressed. Email: fmengelo@ksu.edu.tr

Received: 16 January 2008 / Accepted: 25 January 2008 / Published: 4 February 2008

\begin{abstract}
Thermal behaviors of eucalyptus wood residue (EWR) filled recycled high density polyethylene (HDPE) composites have been measured applying the thermogravimetric analysis (TGA) and differential scanning calorimetry (DSC). Morphology of the materials was also studied using scanning electron microscope (SEM). Addition of the EWR into the recycled HDPE matrix reduced the starting of degradation temperature. EWR filled recycled HDPE had two main decomposition peaks, one for EWR around $350{ }^{\circ} \mathrm{C}$ and one for recycled HDPE around $460{ }^{\circ} \mathrm{C}$. Addition of EWR did not affect the melting temperature of the recycled HDPE. Morphological study showed that addition of coupling agent improved the compatibility between wood residue and recycled HDPE.
\end{abstract}

Keywords: Thermogravimetric analysis, differential scanning calorimetry, scanning electron microscope, high density polyethylene, coupling agent.

\section{Introduction}

In the last twenty years, the use of lignocellulosic fibers as filler in the plastic industry has increased progressively [1]. Thermoplastics are combined with lignocellulosic (wood) fillers to produce woodplastic composites (WPC). They provide several advantages such as low densities, low cost, nonabrasive nature [1-4], possibility of high filling levels, low energy consumption, high specific properties, biodegradability, availability of a wide variety of fibers throughout the world, and generation of a rural/agricultural-based economy [5-6]. In addition, the utilization of recycled plastic 
and waste wood in the manufacturing of such composites may help the environment by reducing the land filling and/or promoting the recycling.

First patented application of WPC was to manufacture of automotive interior substrates using extruded polypropylene and wood flour [1,7-8]. After this Italian patent, other companies started to produce various shapes of automotive parts by extruding polypropylene and wood flour mixtures. In recent times, WPCs have found other application areas including siding, fencing, window frames and decking [1,7-12] by using polypropylene as well as high density polyethylene (HDPE) and polyvinyl chloride (PVC) as matrix resins.

Several studies were conducted to evaluate the performance of WPCs. Most of them has focused on to improve the compatibility between hydrophobic (non-polar) thermoplastics and hydrophilic (polar) wood flours [1,11-14]. In order to enhance similarity and adhesion between wood-flours and thermoplastic matrices, several chemicals have been employed [15-24]. Lu et al. [25] classified the maleic anhydride grafted polyolefin as the most suitable chemicals for polyolefins. The effects of coupling agents on the mechanical properties of HDPE and PP based wood composites were investigated extensively [26-33]. A few researches were conducted to investigate the thermal and morphological behavior of WPCs. It is the purpose of this study to understand the behavior of the thermoplastic matrices with lignocellulosic filler such as eucalyptus wood residues. Study also investigated the effect of maleic anhydride grafted polyethylene as a coupling agent on the mechanical properties and the morphology of the composites.

\section{Results and Discussion}

\subsection{Thermogravimetric analysis (TGA) and Differential scanning calorimetry (DSC) results}

TGA analysis was performed on eucalyptus wood residue (EWR), unfilled recycled HDPE (A), EWR filled recycled HDPE composites (B), and EWR filled recycled HDPE composites modified with MAPE coupling agent (C). Figure 1 shows the TGA thermographs of the samples. Initial degradation of EWR was started around $220^{\circ} \mathrm{C}$ while recycled HDPE started around $300{ }^{\circ} \mathrm{C}$. Composite materials started degrading $250{ }^{\circ} \mathrm{C}$ and $260{ }^{\circ} \mathrm{C}$ for sample $\mathrm{B}$ and $\mathrm{C}$, respectively. Addition of EWR into the thermoplastic matrix induced recycled HDPE to degrade thermally at low temperatures [34]. It is reported that thermal degradation of wood produces free radicals which accelerate the reaction of thermal degradation of polyethylene at high temperatures [34-35]. Figure 2 shows the TGA and DTGA thermographs of the sample B. The two main decomposition peaks was shown with arrows on DTGA thermograph. The first peak was around $350{ }^{\circ} \mathrm{C}$ while the second peak was around $450^{\circ} \mathrm{C}$. It is believed that first peak of $350{ }^{\circ} \mathrm{C}$ in composite B was mainly coming from the degradation of EWR. The main decomposition temperature of EWR was $360^{\circ} \mathrm{C}$ (Table 1). Second decomposition temperature peak for HDPE based composites was close to the decomposition temperature of recycled $\operatorname{HDPE}\left(470^{\circ} \mathrm{C}\right)$. Similar results were also observed for sample $\mathrm{C}$. 


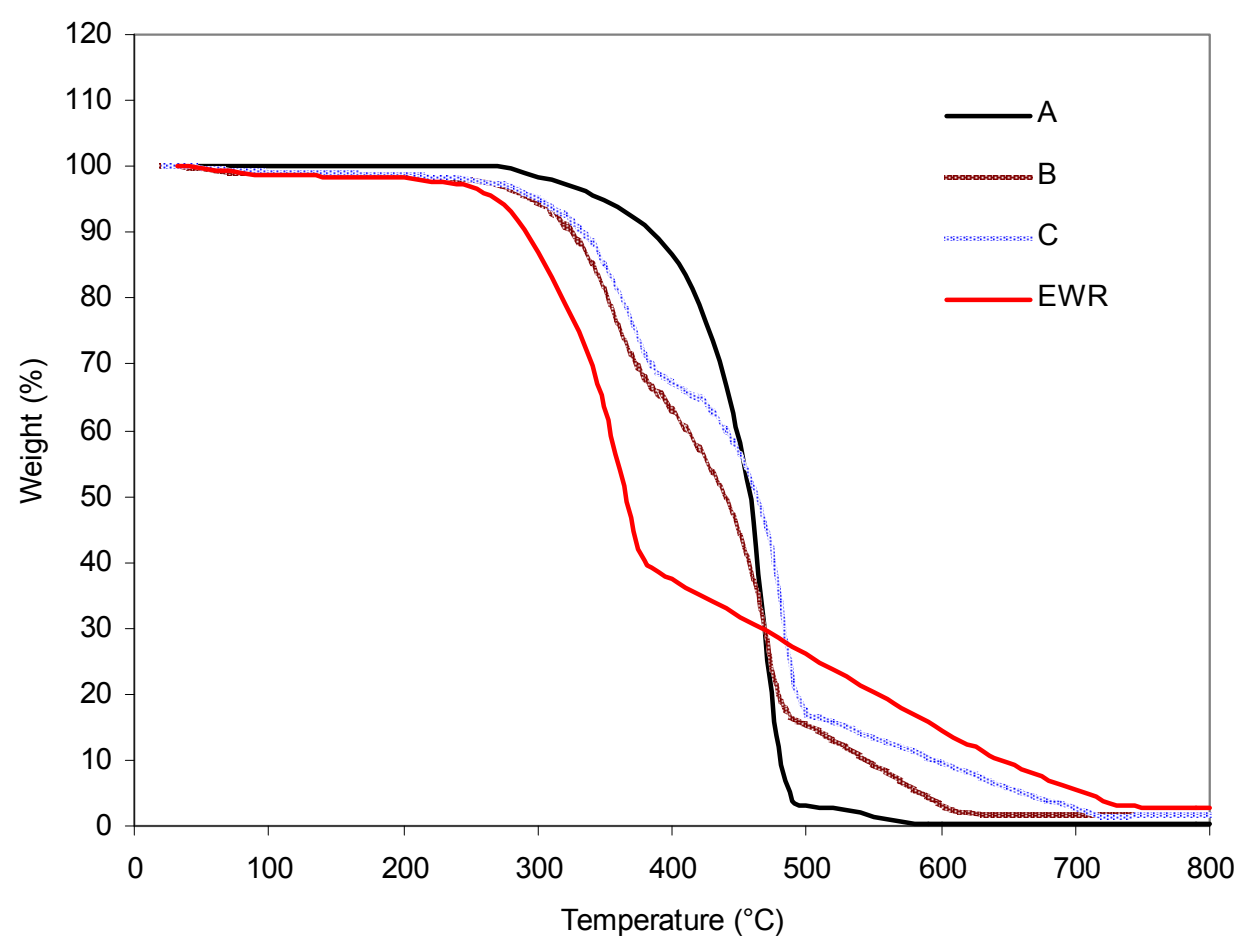

Figure 1. TGA thermographs of unfilled recycled HDPE (A), EWR filled recycled HDPE composites (B), EWR filled recycled HDPE composites modified with MAPE coupling agent (C) and eucalyptus wood residue (EWR).

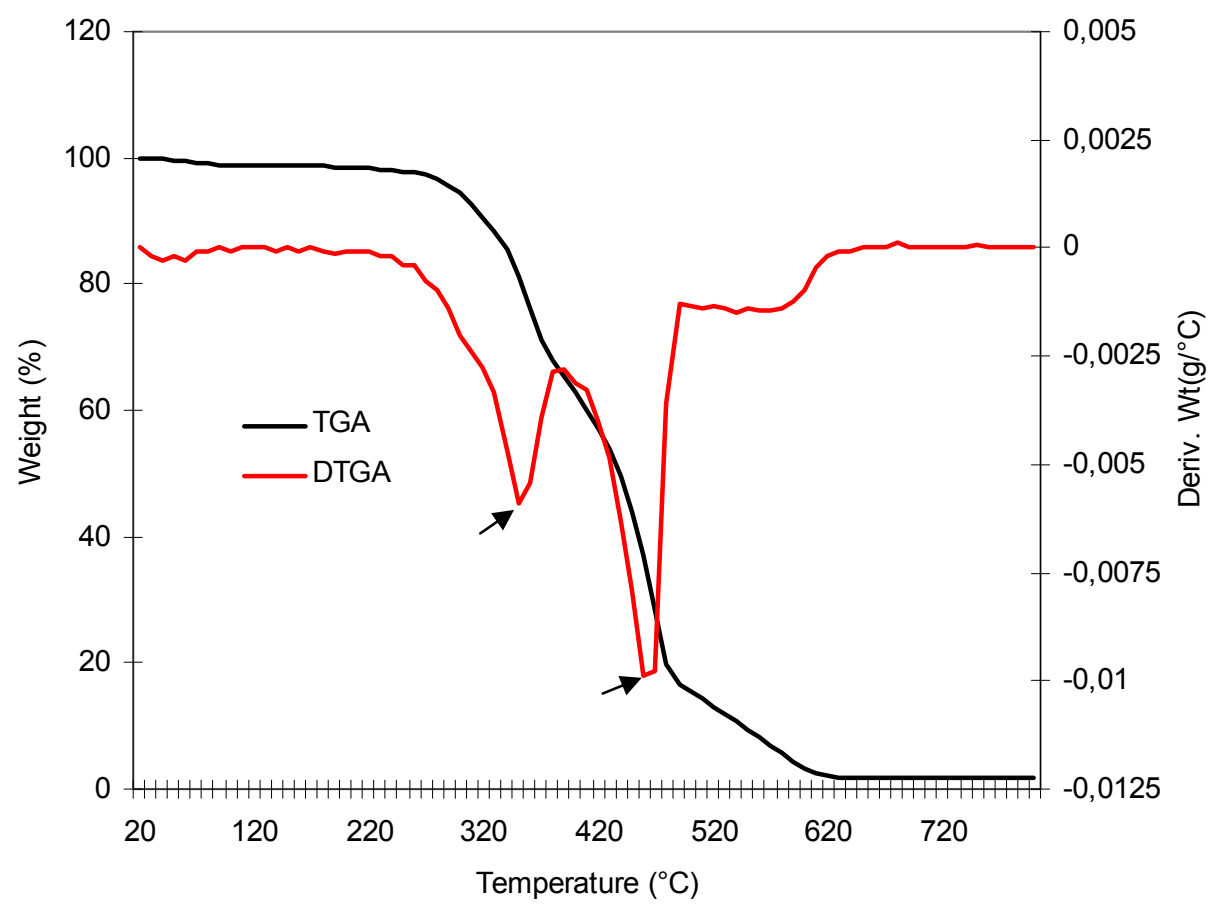

Figure 2. TGA and DTGA thermographs of the eucalyptus wood residue filled recycled HDPE composites. 
Summary of onset degradation, peak temperature and residual weight after $500{ }^{\circ} \mathrm{C}$ of the materials are also given in Table 1. When the residues of the samples at $500{ }^{\circ} \mathrm{C}$ were compared, EWR and recycled HDPE had 26-percent and 3-percent residues, respectively. In composite $\mathrm{B}$ and $\mathrm{C}$, residues were around 16-percent and 17-percent, respectively. Addition of EWR into the recycled HDPE increased the remaining residues due to the charring of EWR.

Table 1. Thermogravimetric data for eucalyptus wood residue (EWR), recycled HDPE (A), EWR filled recycled HDPE composites (B), EWR filled recycled HDPE composites modified with MAPE coupling agent $(\mathrm{C})$.

\begin{tabular}{|c|c|c|c|c|c|c|}
\hline$I D$ & $\begin{array}{c}\text { Onset Temperature } \\
\left({ }^{\circ} \mathrm{C}\right)\end{array}$ & \multicolumn{2}{|c|}{ Peak Temperature $\left({ }^{\circ} \mathrm{C}\right)$} & \multicolumn{2}{|c|}{ Weight Loss (\%) } & $\begin{array}{c}\text { Residue after } \\
500{ }^{\circ} \mathrm{C}(\%)\end{array}$ \\
\hline EWR & $315(2.4)^{1}$ & \multicolumn{2}{|c|}{$360(7.0)$} & \multicolumn{2}{|c|}{$46(1.5)$} & $26(3.0)$ \\
\hline \multirow[t]{2}{*}{ A } & $434(1.2)$ & \multicolumn{2}{|c|}{$470(0.8)$} & \multicolumn{2}{|c|}{$71(2.0)$} & $3(2.9)$ \\
\hline & & $1^{s t}$ peak & $2^{\text {nd }}$ peak & $1^{s t}$ peak & $2^{\text {nd }}$ peak & \\
\hline B & $404(1.0)$ & $350(0.2)$ & $450(0.15)$ & $19(0.41)$ & $56(1.53)$ & $16(1.0)$ \\
\hline $\mathrm{C}$ & $429(0.52)$ & $360(0.07)$ & $480(0.2)$ & $19(0.44)$ & $66(1.32)$ & $17(0.1)$ \\
\hline
\end{tabular}

${ }^{1}$ The value in parenthesis is the standard deviation.

Thermal properties of the materials based on DSC results were presented in Table 2. DSC thermographs of the samples were shown in Figure 3. Melting temperature of the recycled HDPE and their composites was around $128-130^{\circ} \mathrm{C}$.

Table 2. Thermal properties of DSC for the recycled HDPE (A), eucalyptus residue filled recycled HDPE composites (B) and eucalyptus wood residue filled recycled HDPE modified with MAPE coupling agent $(\mathrm{C})$.

\begin{tabular}{ccccc}
\hline ID & $\begin{array}{c}\text { Wood Content } \\
(\%)\end{array}$ & $\begin{array}{c}\text { HDPE Content } \\
(\%)\end{array}$ & $\begin{array}{c}\text { Melt Temperature } \\
\left({ }^{\circ} \mathrm{C}\right)\end{array}$ & $\begin{array}{c}\text { Melt Enthalpy } \\
\Delta H m(\mathrm{~J} / \mathrm{g})\end{array}$ \\
\hline $\mathrm{A}$ & - & 100 & 130 & 152 \\
$\mathrm{~B}$ & 50 & 50 & 129 & 88 \\
$\mathrm{C}$ & 50 & $46+4$ & 129 & 72 \\
\hline
\end{tabular}

Based on the TGA and DSC analysis during the manufacturing of the composites, extruder temperatures should be over $129^{\circ} \mathrm{C}$ for HDPE to facilitate the melting of the matrix and should be less than $220{ }^{\circ} \mathrm{C}$ to prevent the lignocellulosic material from degrading. It should also be noted that residence time of the material in the extruder is also important [36]. Higher processing temperature can be set if the component passes through the extruder in a short time. 


\subsection{Effect of MAPE Coupling Agent on Mechanical Properties}

Table 3 summarizes the mechanical properties of eucalyptus wood residue (EWR) filled recycled thermoplastic composites. Mechanical properties were discussed under three headings; tensile properties, flexural properties and impact properties.

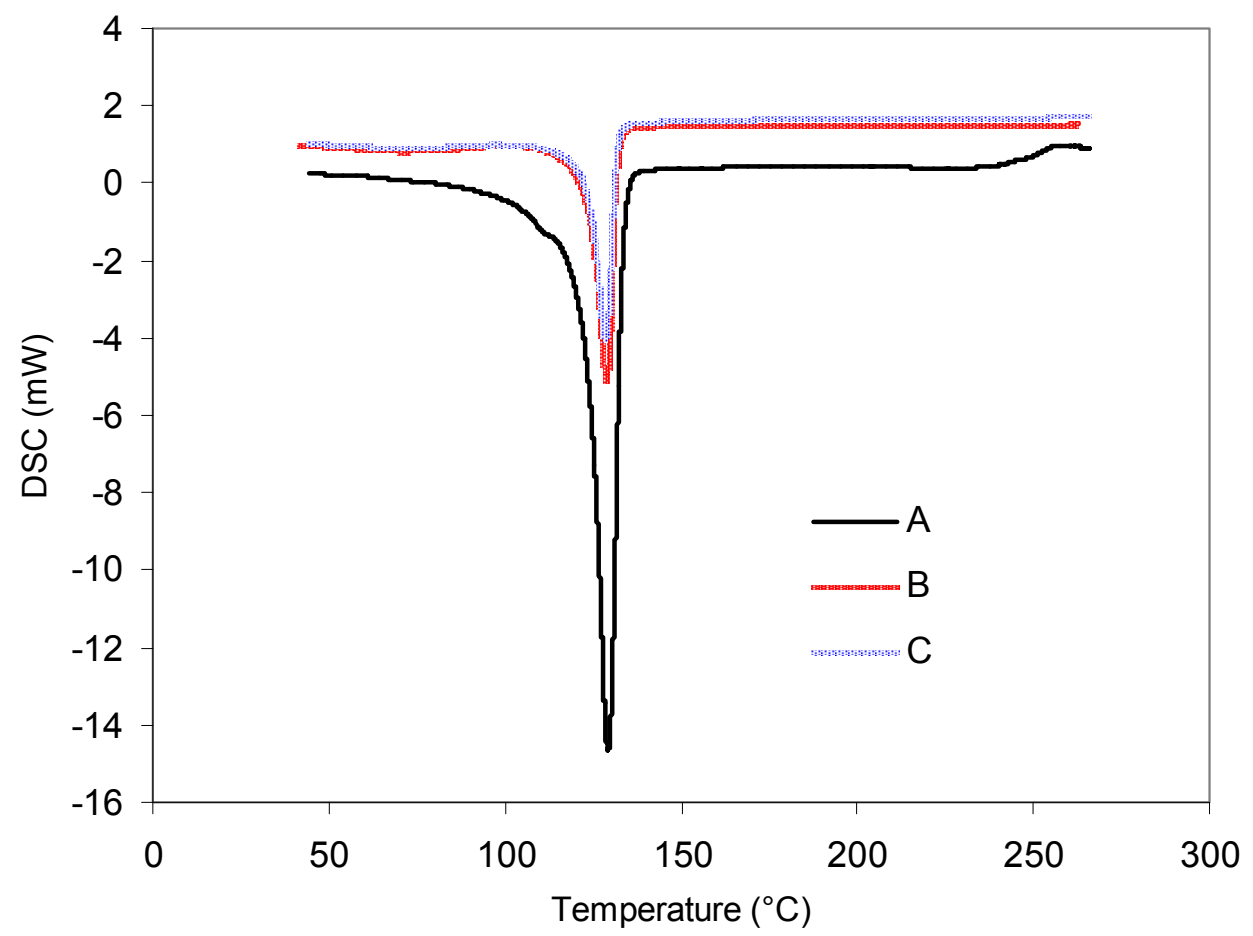

Figure 3. DSC thermographs of the recycled HDPE (A), eucalyptus residue filled recycled HDPE composites (B) and eucalyptus wood residue filled recycled HDPE modified with MAPE coupling agent $(\mathrm{C})$.

Table 3. Mechanical properties of EWR filled recycled HDPE (B) and EWR filled recycled HDPE composites modified with MAPE coupling agent (C).

\begin{tabular}{lcccccc}
\hline \multicolumn{1}{c}{ Specimen ID } & $\begin{array}{c}\text { Tensile } \\
\text { Strength } \\
(\mathrm{MPa})^{1}\end{array}$ & $\begin{array}{c}\text { Tensile } \\
\text { Modulus } \\
(\mathrm{MPa})\end{array}$ & $\begin{array}{c}\text { Elongation } \\
\text { at Break } \\
(\%)\end{array}$ & $\begin{array}{c}\text { Flexural } \\
\text { Strength } \\
(\mathrm{MPa})\end{array}$ & $\begin{array}{c}\text { Flexural } \\
\text { Modulus } \\
(\mathrm{MPa})\end{array}$ & $\begin{array}{c}\text { Impact } \\
\text { Strength } \\
(\mathrm{J} / \mathrm{m})\end{array}$ \\
\hline B & $6.44^{1}$ & 253.6 & 3.23 & 14.72 & 1246.5 & 30.04 \\
(no coupling agent) & $(0.34)^{2}$ & $(30.2)$ & $(0.36)$ & $(0.70)$ & $(68.0)$ & $(0.68)$ \\
C & 9.58 & 329.3 & 3.37 & 17.16 & 1304.3 & 28.17 \\
(4\% coupling agent) & $(0.41)$ & $(32.3)$ & $(0.21)$ & $(0.90)$ & $(68.0)$ & $(1.20)$ \\
\hline
\end{tabular}

\footnotetext{
${ }^{1}$ Each value is the average of 7 samples tested.
}

2 The value in parenthesis is the standard deviation. 
Tensile properties include tensile strength, tensile modulus and elongation at break. Table 4 summarizes the analysis of variance for tensile properties of EWR filled recycled HDPE composites. The ANOVA showed that addition of coupling agent significantly improved the tensile strength $(\mathrm{P}<0.0001)$. Similar results were also reported by others [37-40]. It is believed that better wetting of the PE based maleic anhydride to the HDPE matrix polymer is responsible for improved results. Addition of MAPE coupling agent significantly advanced the tensile modulus of the composites $(\mathrm{P}=0.0007)$ due to the improved adhesion between plastic and EWRs. Similar results for other wood flours filled polymer composites were also reported $[19,41]$. In the case of elongation at break, coupling agent had no significant effect $(\mathrm{P}=0.4087)$ on composites.

Table 4. Analysis of variance for tensile properties of eucalyptus residue filled recycled HDPE composites.

\begin{tabular}{llrrrrr}
\hline $\begin{array}{l}\text { Dependent } \\
\text { Variable }\end{array}$ & Source of variation & $S S$ & DF & MS & $F$ & $P$ \\
\hline Tensile Strength & Effect of Coupling & 34.54 & 1 & 34.54 & 241.27 & $<0,0001$ \\
& Agent (CA) & & & & & \\
& Pure Error & 1.72 & 12 & 0.14 & & \\
& Total & 36.26 & 13 & & & \\
\hline Tensile Modulus & Effect of CA & 20068 & 1 & 20068 & 20.48 & 0.0007 \\
& Pure Error & 11760 & 12 & 979.97 & & \\
& Total & 31828 & 13 & & & 0.4087 \\
\hline Elongation at & Effect of CA & 0.64 & 1 & 0.64 & 0.73 & \\
Break & Pure Error & 1.06 & 12 & 0.88 & & \\
& Total & 1.12 & 13 & & & \\
\hline
\end{tabular}

Flexural properties include flexural strength and flexural modulus (Table 3). Table 5 summarizes the analysis of variance for flexural properties of EWR filled recycled HDPE composites. Addition of coupling agent significantly improved the flexural strength $(\mathrm{P}=0.0001)$. Similar results were also reported in the flexural strength of other wood flour filled thermoplastic composites [37-39]. For polyolefin-based plastic lumber decking boards, ASTM D 6662 (2001) standard requires the minimum flexural strength of $6.9 \mathrm{MPa}(1,000 \mathrm{psi})$. All composites produced in this study provided flexural strength values (14-17 MPa) that are well over the requirement by the standard. In the case of flexural modulus, addition of coupling agent improved the flexural strength but this increase was not statistically significant $(\mathrm{P}=0.1378)$. ASTM D 6662 (2001) standard requires the minimum flexural modulus of $340 \mathrm{MPa}(50,000 \mathrm{psi})$ for polyolefin-based plastic lumber decking boards. All composites produced in this study provided flexural modulus values (1250-1300 MPa) well over required standards. 
Table 5. Analysis of variance for flexural properties of eucalyptus residue filled recycled HDPE composites.

\begin{tabular}{llrrrrr}
\hline $\begin{array}{l}\text { Dependent } \\
\text { Variable }\end{array}$ & Source of variation & $S S$ & DF & MS & $F$ & $P$ \\
\hline Flexural Strength & Effect of CA & 20.86 & 1 & 20.86 & 32.02 & 0.0001 \\
& Pure Error & 7.82 & 12 & 0.65 & & \\
& Total & 28.68 & 13 & & & \\
\hline Flexural Modulus & Effect of CA & 11678 & 1 & 11678 & 2.53 & 0.1378 \\
& Pure Error & 55440 & 12 & 4620 & & \\
& Total & 67118 & 13 & & & \\
& & & & & & \\
\hline
\end{tabular}

Table 6 summarizes the analysis of variance for impact strength of EWR filled recycled HDPE composites. Addition of coupling agent reduced the Izod impact strength significantly $(\mathrm{P}=0.0037)$. In composite materials, improved adhesion usually changes the mode of failure from "fiber pull out" to fiber breakage, which usually requires less energy. Similar findings were reported in other studies for different wood flours or fibers [2].

Table 6. Analysis of variance for impact properties of eucalyptus residue filled recycled HDPE composites.

\begin{tabular}{llrrrrr}
\hline $\begin{array}{l}\text { Dependent } \\
\text { Variable }\end{array}$ & Source of variation & SS & DF & MS & $F$ & $P$ \\
\hline Impact Strength & Effect of CA & 12.22 & 1 & 12.22 & 12.93 & 0.0037 \\
& Pure Error & 11.34 & 12 & 0.95 & & \\
& Total & 23.56 & 13 & & & \\
\hline
\end{tabular}

\subsection{Morphology}

Morphology of the eucalyptus wood residue (EWR) filled recycled HDPE composites were studied using SEM micrographs. Figure 4 shows the fractured surface of unfilled recycled HDPE, EWR filled recycled HDPE composites and MAPE modified EWR filled recycled HDPE composites. When Figure $4 \mathrm{a}$ and $\mathrm{b}$ was compared, it could be seen that matrix with eucalyptus wood residue was stiffer than other. In Figure 4 b, the arrows show the individual eucalyptus wood residues in the matrix. This result was due to the poor adhesion between the not compatible EWRs (hydrophilic) and recycled HDPE matrix (hydrophobic). Figure 4c presents the EWR filled recycled HDPE composites with 4percent MAPE coupling agents. Some wood residues were embedded into the recycled HDPE matrix indicating improved adhesion. However, there were still individual wood residues on the interface of eucalyptus wood residue and recycled HDPE matrix. 

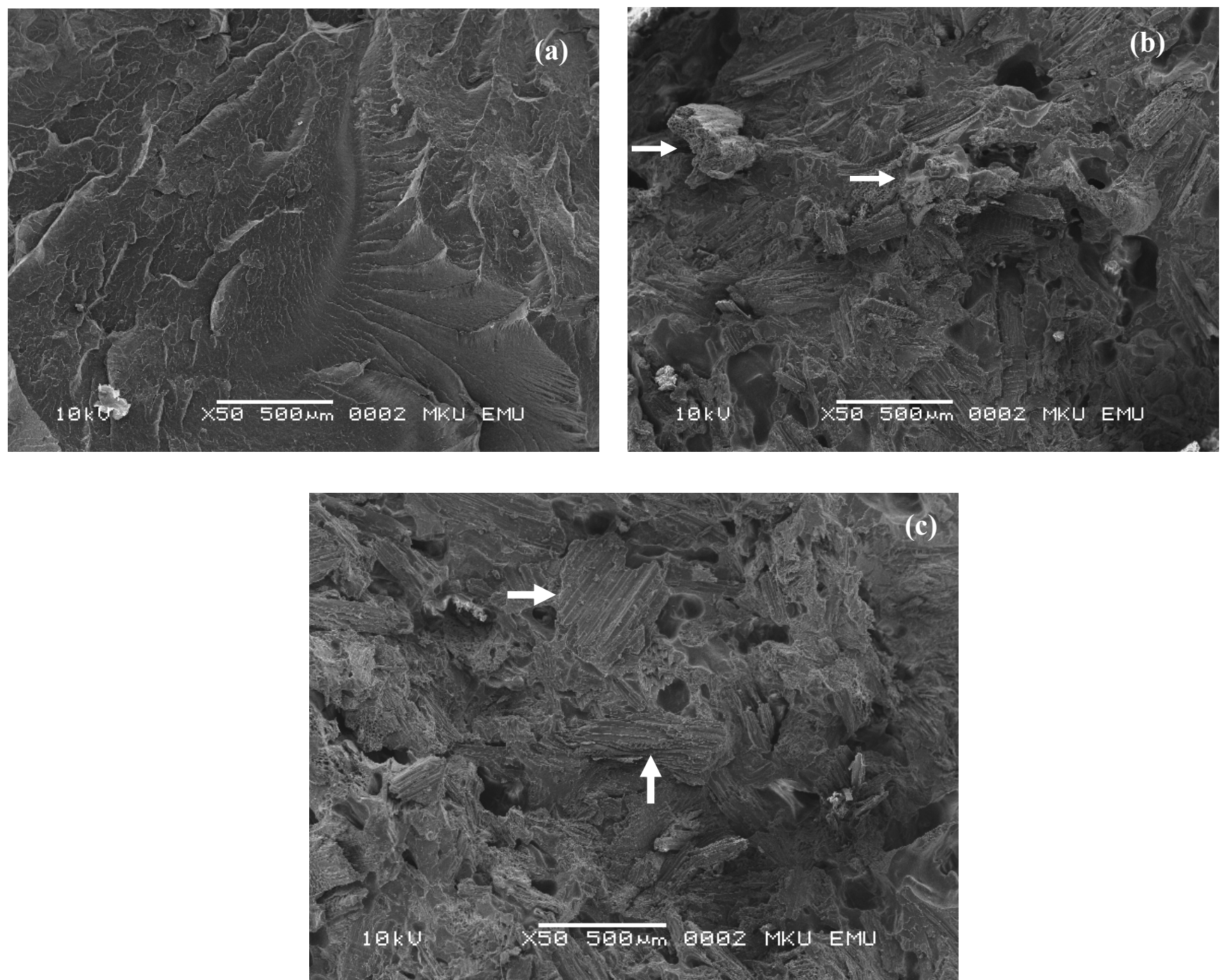

Figure 4. SEM micrographs of the a) unfilled recycled HDPE, b) eucalyptus wood residue filled recycled HDPE composites and c) MAPE modified eucalyptus wood residue filled recycled HDPE composites

\section{Experimental Section}

\subsection{Materials}

Recycled high density polyethylene (HDPE) and eucalyptus wood residues were used as thermoplastic matrix and organic filler, respectively. Recycled HDPE pellets were produced from waste water pipes while eucalyptus residues were collected from lumber mills in the city of Tarsus, Turkey. They were granulated into 40-mesh size flours using Wiley mill. Maleic anhydrite grafted polyethylene (Licocene PEMA 4351 by Clarient) was utilized as coupling agent. Descriptions of coupling agents are provided in Table 7.

\subsection{Compounding of the composites}

Compounding of the composites was implemented using a single screw extruder. Three different panels in Table 8 were manufactured. Depending on the groups, granulated HDPE, eucalyptus wood 
residue (EWR) and MAPE coupling agent were mixed in a high intensity mixer for 5 minutes to produce homogeneous blend. Then this homogenous mixture was compounded in a laboratory scale single-screw extruder at $40 \mathrm{rpm}$ screw speed. Extruder temperatures were set as $170175180185185{ }^{\circ} \mathrm{C}$. The extrudates were collected, cooled and granulated into pellets. Finally, pellets were compression molded in the hot press for 5 minutes at $175^{\circ} \mathrm{C}$ and cooled for 20 minutes. Panels with the size of $5 \times 150 \times 200 \mathrm{~mm}$ were produced.

Table 7. Descriptions of the coupling agents used in this study.

\begin{tabular}{ll}
\hline Descriptions & Licocene PE MA 4351 (MAPE) \\
\hline Appearance & White fine grain \\
Softening point & $123^{\circ} \mathrm{C}$ \\
Acid Value & $43 \mathrm{mg} \mathrm{KOH} / \mathrm{g}$ \\
Density at $23^{\circ} \mathrm{C}$ & $0.99 \mathrm{~g} / \mathrm{cm}^{3}$ \\
Viscosity at $140^{\circ} \mathrm{C}$ & $300 \mathrm{mPa} . \mathrm{s}$ \\
\hline
\end{tabular}

Table 8. Description of the manufactured samples.

\begin{tabular}{cccc}
\hline ID & Recycled HDPE (\%) & Eucalyptus wood residue (\%) & MAPE (\%) \\
\hline A & 100 & - & - \\
B & 50 & 50 & - \\
C & 46 & 50 & 4 \\
\hline
\end{tabular}

\subsection{Thermogravimetry and Differential Scanning Calorimetry}

Thermogravimetric analysis (TGA) of the samples was done in a Shimadzu TGA-50 thermal analyzer using a scanning rate of $10{ }^{\circ} \mathrm{C} / \mathrm{min}$ heating rate under nitrogen with $20 \mathrm{~mL} / \mathrm{min}$ flow rate, from room temperature to $800^{\circ} \mathrm{C}$. Differential scanning calorimeter (DSC) analysis was performed in Shimadzu DSC-60 using $10{ }^{\circ} \mathrm{C} / \mathrm{min}$ heating rate under nitrogen with $30 \mathrm{~mL} / \mathrm{min}$ flow rate, from room temperature to $500{ }^{\circ} \mathrm{C}$.

\subsection{Mechanical Property Testing}

To evaluate the effect of MAPE coupling agent on the mechanical properties of eucalyptus wood residue filled recycled HDPE composites, testing of the flexural, tensile and impact properties were determined in a climate-controlled testing laboratory. The flexural tests were conducted in accordance with ASTM D 790. Ten samples were tested on Zwick 10KN for each group with a crosshead motion rate of $2.0 \mathrm{~mm} / \mathrm{min}$. ASTM D 683 standards were used for tensile tests with a $5.0 \mathrm{~mm} / \mathrm{min}$ test speed. The impact tests were performed according to ASTM D 256. Ten samples for each group were cut from the manufactured composites. The notches were added using a Polytest notching cutter by RayRan ${ }^{\mathrm{TM}}$ and notched samples were tested on a HIT5.5P impact testing machine, manufactured by Zwick ${ }^{\mathrm{TM}}$. At least seven samples were tested for each property. 


\subsection{Scanning Electron Microscope}

The fractured surface of the samples was also studied by using JEOL scanning electron microscope (Model JSM 6400). The samples were first dipped into liquid nitrogen and snapped to half to prepare the fractured surfaces. Then samples were mounted on the sample stub and were sputtered with gold.

\subsection{Statistical Analysis}

Design-Expert ${ }^{\circledR}$ Version 7.0.3 statistical software program was used for statistical analysis. In this study, the general factorial design for one factor was chosen to determine effect of addition of 4percent MAPE coupling agent on the mechanical properties of eucalyptus wood residue filled recycled HDPE composites.

\section{Acknowledgements}

This research was supported by The Scientific \& Technological Research Council of Turkey (Project \# TOVAG 106O548). Authors would also like to thank Mr. Kadir Karakus and Mr. Murat Ertas for the help during composite manufacturing and instrumental analysis.

\section{References and Notes}

1. Clemons, C. Wood-plastic composites in the United States. The interfacing of two industries. Forest Prod. J. 2002, 52, 10-18.

2. Mengeloglu, F.; Matuana, L.M.; King, J. Effects of impact modifiers on the properties of rigid PVC/wood-fiber composites. J. Vinyl. Addit. Techn. 2000, 6(3), 153-157; DOI 10.1002/vnl.10244.

3. Mengeloglu, F.; Matuana, L.M. Mechanical properties of extrusion foamed rigid PVC/Wood-flour composites. J. Vinyl. Addit. Techn. 2003, 9(1), 26-31; DOI 10.1002/vnl.10058.

4. Matuana, L.M.; Park, C.P.; Balatinecz, J.J. Cell morphology and property relationships of microcellular foamed PVC/Wood-fiber composites. Polym. Eng. Sci. 1998, 38, 1862-1872; DOI 10.1002/pen.10356.

5. Abu-Sharkh, B.F.; Kahraman, R.; Abbasi, S.H.; Hussein, I.A. Effect of epolene E-43 as a compatibilizer on the mechanical properties of palm fiber-poly(propylene) composites. J. Appl. Polym. Sci. 2004, 92, 2581-2592; DOI 10.1002/app.20230.

6. Sanadi, A.R.; Caulfield, D.F.; Rowell, R.M. Reinforcing polypropylene with natural fibers. Plast. Eng. 1994, 4, 27-30.

7. Geng, Y.; Li, K.; Simonsen, J. Effect of a new compatibilizer system on the flexural properties of wood-polyethylene composites. J. Appl. Polym. Sci. 2004, 91, 3667-3672; DOI 10.1002/app.13618.

8. Schut, J. For compounding, sheet \& profile: Wood is good. Plast. Technol. 1999, 1999 (March), 46-52. 
9. Winandy, J.E.; Stark, N.M.; Clemons, C. Considerations in recycling of wood-plastic composites. Proc. $5^{\text {th }}$ Global Wood and Natural Fibre Composites Symposium, Kassel, Germany, 2004; No. A6-1.

10. La Mantia, F.P.; Morreale, M.; Ishak, Z.A. Processing and mechanical properties of organic fillerpolypropylene composites. J. Appl. Polym. Sci, 2005, 96, 1906-1913; DOI 10.1002/app.21623.

11. Mengeloglu, F.; Matuana, L.M.; King, J. Effects of impact modifiers on the properties of rigid PVC/wood-fiber composites. J. Vinyl. Addit. Techn. 2000, 6(3), 153-157; DOI 10.1002/vnl.10244.

12. Mengeloglu, F.; Matuana, L.M. Mechanical properties of extrusion foamed rigid PVC/Wood-flour composites. J. Vinyl. Addit. Techn. 2003, 9(1), 26-31; DOI 10.1002/vnl.10058.

13. Sanadi, A.R.; Young, R.A.; Clemons, C.; Rowel, R.M. Recycled newspaper fibers as reinforcing fillers in thermoplastics: Part I - Analysis of tensile and impact properties of polypropylene. $J$. Reinf. Plast. Comp. 1994, 13, 54-58; DOI 10.1177/073168449401300104.

14. Sanadi, A.R.; Caulfield, D.F.; Rowell, R.M. Reinforcing polypropylene with natural fibers. Plast. Eng. 1994, 4, 27-30.

15. Woodhams, R.T.; Thomas, G.; Rodgers, D.K. Wood fibers as reinforcing fillers for polyolefins. Polym. Eng. Sci. 1994, 24, 1166-1171; DOI 10.1002/pen.760241504.

16. Matuana, L.M.; Balatinecz, J.J. Effect of surface properties on the adhesion between PVC and wood veneer laminates. Polym. Eng. Sci. 1998, 38(5), 765-773; DOI 10.1002/pen.10242.

17. Matuana, L.M.; Balatinecz, J.J.; Park, C.B.; Sodhi, R.N.S. X-ray photoelectron spectroscopy study of silane-treated newsprint-fibers. Wood Sci. Technol. 1999, 33(4), 259-270; DOI $10.1007 / \mathrm{s} 002260050114$.

18. Qiu, W.; Endo, T.; Hirotsu, T. Interfacial interactions of a novel mechanochemical composite of cellulose with maleated polypropylene. J. Appl. Polym. Sci. 2004, 94, 1326-1335; DOI 10.1002/app.21123.

19. Coutinho, F.M.B.; Costa, T.H.S.; Carvalho, C.D.L. Polypropylene-wood fiber composites: Effect of treatment and mixing conditions on mechanical properties. J. Appl. Polym. Sci. 1998, 65, $1227-$ 1235; DOI 10.1002/(SICI)1097-4628(19970808)65:6<1227::AID-APP18>3.0.CO;2-Q.

20. Qiu, W.; Zhang, F.T.; Endo, T.; Hirotsu, T. Milling-induced etherification between cellulose and maleated polypropylene. J. Appl. Polym. Sci. 2003, 91, 1703-1709; DOI 10.1002/app.13368.

21. Qiu, W.; Zhang, F.T.; Hirotsu, T. Isocyanate as a compatibilizing agent on the properties of highly Crystalline cellulose/polypropylene composites. J. Mater. Sci. 2005, 40, 3607-3614.

22. Qiu, W.; Zhang, F.T.; Endo, T.; Hirotsu, T. Effect of maleated polypropylene on the performance of polypropylene/cellulose composite. Polym. Comp. 2005, 26, 448-453; DOI 10.1002/pc.20119.

23. Lu, J.Z.; Wu, Q.; Negulescu, I.I. Wood-fiber/high-density-polyethylene composites: Coupling agent Performance. J. Appl. Polym. Sci. 2005, 96, 93-102; DOI 10.1002/app.21410.

24. Jana, C.J.; Prieto, A. Natural fiber composites of high-temperature thermoplastics polymers: Effect of coupling agents. J. Appl. Polym. Sci. 2002, 86, 2168-2173; DOI 10.1002/app.11072.

25. Lu, J.Z.; Wu, Q.; McNabb, H.S. Chemical coupling in wood fiber and polymer composites: A review of coupling and treatments. Wood Fiber Sci. 2000, 32, 88-104. 
26. Mengeloglu, F.; Kurt, R.; Gardner, D.J.; O’Neill, S. Mechanical properties of extruded high density polyethylene (HDPE)- and polypropylene (PP)- wood flour decking boards. Iran Polym. J. 2007, 16(7), 477-487.

27. Yang, H.S.; Wolcott, M.P.; Kim, H.S.; Kim, S.; Kim, H.J. Effect of different compatibilizing agents on the mechanical properties of lignocellulosic material filled polyethylene bio-composites. Compos. Struct. 2007, 79, 369-375; DOI 10.1016/j.compstruct.2006.02.016.

28. Li, Q.; Matuana, L.M. Effectiveness of maleated and acryclic acid-functionalized polyolefin coupling agents for HDPE-wood-flour composites. J. Thermoplast. Compos. 2003, 16, 551-564; DOI $10.1177 / 089270503033340$.

29. Lai, S.M.; Yeh, F.C.; Wang, Y.; Chan, H.C.; Shen, H.F. Comparative study of maleated polyolefins as compatibilizers for polyethylene/wood flour composites. J. Appl. Polym. Sci. 2003, 87, 487-496; DOI 10.1002/app.11419.

30. Wang, Y.; Yeh, F.C.; Lai, S.M.; Chan, H.C.; Shen, H.F. Effectiveness of functionalized polyolefins as compatibilizers for polyethylene/wood flour composites. Polym. Eng. Sci. 2003, 43(4), 933-945; DOI 10.1002/pen.10077.

31. Yamaguchi, Y.; Miyata, H. Influence of stereoregularity of polypropylene on miscibility with ethylene-1-hexene copolymer. Macromolecules 1999, 32(18), 5911-5916; DOI $10.1021 / \mathrm{ma} 990004 \mathrm{~s}$.

32. Selke, S.E.; Childress, J. Wood fiber /high-density polyethylene composites: ability of additive to enhance mechanical properties. In Proc. Wood-fiber/Polymer Composites: Fundamental Concepts, Processes, and Material Options; Forest Products Society: Madison, Wisconsin, USA, 1993; p. 109.

33. Sombatsompop, N.; Yotinwattanakumtorn, C.; Thongpin, C. Influence of type and concentration of maleic anhydride grafted polypropylene and impact modifiers on mechanical properties of PP/Wood sawdust composites. J. Appl. Polym. Sci. 2005, 97, 475-484; DOI 10.1002/app.21765.

34. Li, B.; He, J. Investigation of mechanical property, flame retardancy and thermal degradation of LLDPE-wood-fibre composites. Polym. Degrad. Stabil. 2004, 83, 241-246; DOI 10.1016/S01413910(03)00268-4.

35. Amen-Chen, C. Production of monomeric phenols by thermochemical conversion of biomass: a review. Bioresour. Technol. 2001, 79, 277-299; DOI 10.1016/S0960-8524(00)00180-2; PubMed 11499582.

36. Chan, J.H.; Balke, S.T. The thermal degradation kinetics of polypropylene: Part II. Timetemperature superposition. Polym. Degrad. Stabil. 1997, 57, 127-134; DOI 10.1016/S01413910(96)00159-0.

37. Yang, H.S.; Wolcott, M.P.; Kim, H.S.; Kim, S.; Kim, H.J. Effect of different compatibilizing agents on the mechanical properties of lignocellulosic material filled polyethylene bio-composites. Compos. Struct. 2007, 79, 369-375; DOI 10.1016/j.compstruct.2006.02.016. 
38. Li, Q.; Matuana, L.M. Effectiveness of maleated and acryclic acid-functionalized polyolefin coupling agents for HDPE-wood-flour composites. J. Thermoplast. Compos. 2003, 16, 551-564; DOI 10.1177/089270503033340.

39. Lai, S. Comparative study of maleated polyolefins as compatibilizers for polyethylene/wood flour composites. J. Appl. Polym. Sci. 2003, 87, 487-496; DOI 10.1002/app.11419.

40. Wang, Y.; Yeh, F.C.; Lai, S.M.; Chan, H.C.; Shen, H.F. Effectiveness of functionalized polyolefins as compatibilizers for polyethylene/wood flour composites. Polym. Eng. Sci. 2003, 43(4), 933-945; DOI 10.1002/pen.10077.

41. Sombatsompop, N.; Yotinwattanakumtorn, C.; Thongpin, C. Influence of type and concentration of maleic anhydride grafted polypropylene and impact modifiers on mechanical properties of PP/Wood sawdust composites. J. Appl. Polym. Sci. 2005, 97, 475-484; DOI 10.1002/app.21765.

(C) 2008 by MDPI (http://www.mdpi.org). Reproduction is permitted for noncommercial purposes. 